\title{
THE DOBROE 9 SITE: A STRATIFIED EARLY NEOLITHIC COMPLEX IN THE UPPER DON RIVER
}

\author{
ELIZAVETA YURKINA', ROMAN SMOL'YANINOV', ALEXEY KULICHKOV', MARIANNA KUL'KOVA4, \\ ANDREY ZHELUDKOV ${ }^{3}$, YEVHENIIA YANISH ${ }^{5}$, DIANA SHATROVAYA ${ }^{6}$
}

\begin{abstract}
The Middle Don Culture, distributed within the Middle and Upper Don River area, is thought to be one of the earliest Eastern European Neolithic cultures, and is dated to the 6th-5th millennium BC. A group of Neolithic sites was found on the right shore of the Voronezh River, and has been named the "Dobroe sites". The Dobroe 9 settlement is one of few sites in this region at which an assemblage of Middle Don Culture has been recorded in a clear stratigraphic position. The numerous faunal remains, ceramic complex and stone inventory found at this site allows for a reconstruction of the earliest stages of the Neolithic. The elaborated ceramic typology suggests a gradual transformation of the local culture. The particularity of sedimentation process and deposition of artefacts allowed a precise correlation of stone inventory types with early-Neolithic ceramic types. Preliminary reconstructions of palaeoclimate and episodes of human activity for this time period were implemented based on geochemical methods.
\end{abstract}

Key words: Early Neolithic, Middle Don Culture, pottery, flint, stratigraphy, geochemical indication, radiocarbon analysis

\section{Introduction}

Neolithic sites of the forest-steppe Don have been known since 1904 (Zamyatnin 1922). Pottery appears to be the main indicator of the beginning of the Neolithic for this region and for the whole European part of Russia (Sinyuk 1986). Archaeological cultures are distinguished here based mainly on particular ceramic complexes existing in various regions (Levenok 1965; Sinyuk 1986; Smolyaninov et al. 2017). The Middle Don Culture distributed within the Middle and Upper Don River area is thought to be one of the earliest Eastern European Neolithic cultures (Smolyaninov et al. 2017).

The forest-steppe Don Region includes territories stretching within the upper and middle cour- ses of the Don River with its tributaries. The Don River flows from north to south (Fig. 1).

Forest-steppe is a temperate zone landscape that is transitional from forest to steppe, and is characterised in its virgin state by alternation of closed, mostly deciduous forests on grey forest (forest-steppe) soils with mixed grass steppes on chernozems (Mil'kov 1961). The Neolithic sites are located in similar landscape conditions. The sites are located on the shore bank, the ends of the first terrace above the floodplain, and occasionally on the valley sides of the rivers. Their greatest number is located on the floodplains of medium-width rivers such as the Voronezh River, Bityug River, Savala River and Tikhaya Sosna River. These floodplains are covered by water during spring floods.

\footnotetext{
${ }^{1}$ Lipetsk State Pedagogical P.P. Semyonov-Tyan-Shansky University, Lenina St. 42, 398020 Lipetsk, Russia; e-mail: eli9725@mail.ru, ORCID: 0000-0001-9903-3483

${ }^{2}$ Lipetsk State Pedagogical P.P. Semyonov-Tyan-Shansky University, Lenina St. 42, 398020 Lipetsk, Russia; e-mail: rws17rws17@yandex.ru, ORCID: 0000-0001-9018-8753

${ }^{3}$ Lipetsk regional scientific public organisation "Archaeological research", Teperika St. 13/1398004, Lipetsk, Russia; e-mail: kulichckov.aleks@yandex.ru, ORCID:0000-0003-1992-283; aszheludkov@gmail.com, ORCID: 0000-0003-19209106

${ }^{4}$ Herzen State Pedagogical University, Kazanskaya St. 6, 191186 Saint Petersburg, Russia; e-mail: kulkova@mail.ru, ORCID: 0000-0001-9946-8751

${ }^{5}$ I.I. Schmalhausen Institute of Zoology, National Academy of Sciences of Ukraine, Bohdan Khmelnytsky St. 15, 01601 Kyiv, Ukraine; e-mail: tinel@ukr.net, ORCID: 0000-0001-7446-8392

${ }^{6}$ Herzen State Pedagogical University, Kazanskaya St. 6, 191186 Saint Petersburg, Russia; e-mail: diana_shatrovaya @)mail.ru, ORCID: 0000-0002-8459-287X
} 


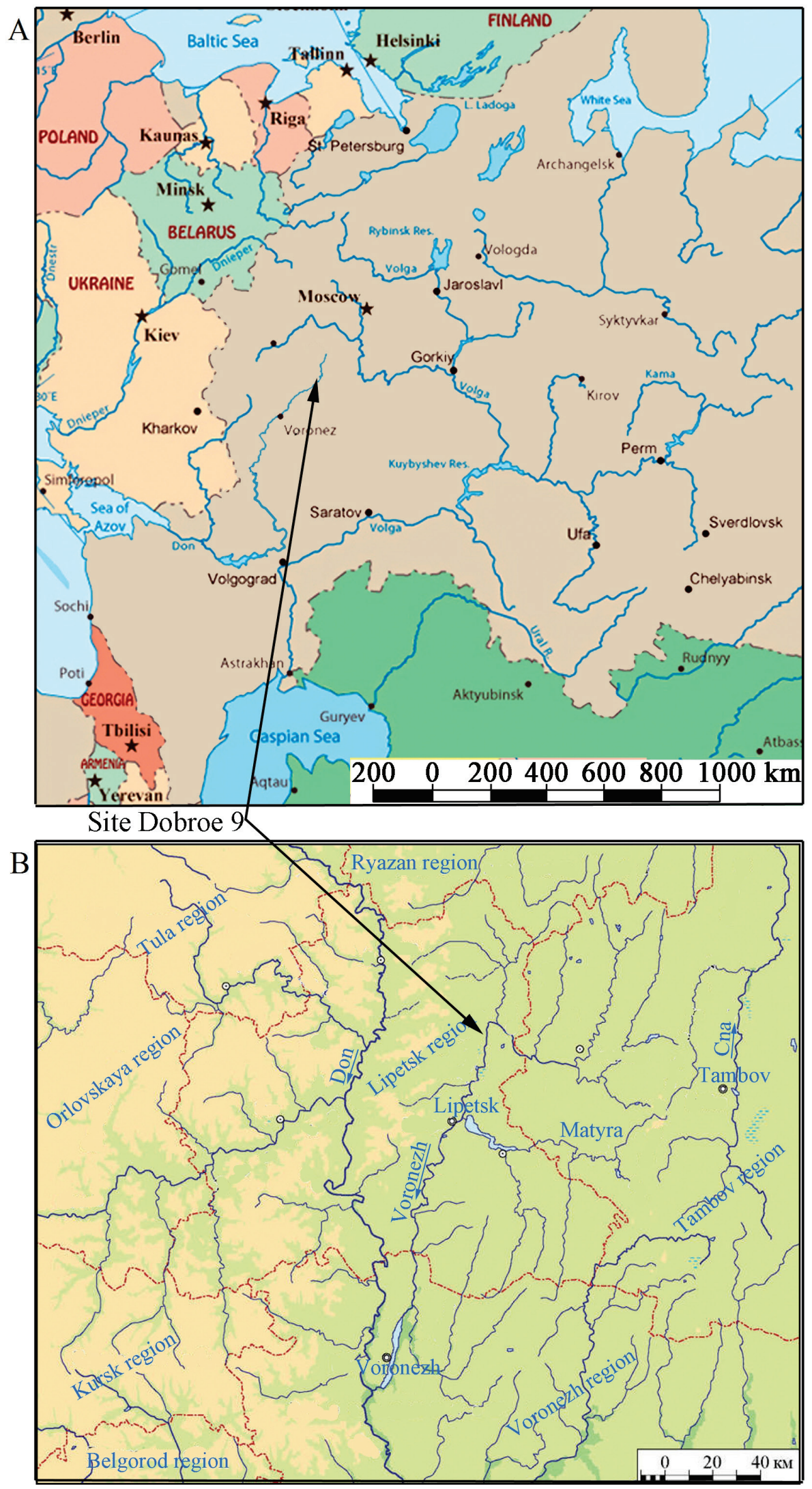

Fig. 1. Location of Dobroe 9 site A - in Eastern Europe, B - in the Central Black Earth Region 
More than 100 sites of the Middle Don Culture are known in this region. Archaeological layers contain materials attributed to a wider chronological timeframe that is not distributed in a clear stratigraphic sequence. This makes it more complicated to precisely correlate different categories of materials and to suggest palaeoclimatic reconstructions for exact periods. The Dobroe 9 settlement is one of few sites in this region at which an assemblage of Middle Don Culture has been recorded in a clear stratigraphic position. The article is focused on: 1) the description of the main cultural features of the Early Neolithic archaeological materials based on the stratigraphic context documented at the unique Dobroe 9 archaeological site; 2) reconstruction of the site's settlement pattern, and 3) reconstructing the environmental conditions of the Early Neolithic communities in the Upper Don River region.

Numerous faunal remains, the ceramic complex and the stone inventory found at this site allow a reconstruction of the earliest stages of the Neolithic. The elaborated ceramic typology suggests a gradual transformation of the local culture. This contributes to the wider problem of earlier phases of Neolithisation in this particular region, which is shown for the first time.

\section{Chronology of the Middle Don Culture}

The materials of the Dobroe 9 site are part of the wider cultural context of the Middle Don Culture, and have been attributed to three chronological stages.

The first stage of the Middle Don Culture includes pottery decorated with geometrical patterns made of triangular-form impressions. They were found at the Monastyrskaya site in the Bityug River basin, in the lower layer of the Cherkasskaya site (excavations of A.T. Sinyuk 1979-1981), and at Inyasevskaya, Shapkinskaya 6, Plautinskaya 2 sites situated in the Khoper River basin. On the Upper Don, similar materials were found only in the layers of the Yarlukovskaya Protoka site, the Dobroe 4 site and Universitetskaya 3 . This stage is dated to the $6^{\text {th }}$ millennium BC: the Dobroe 4 site $-6912 \pm 120$ $\mathrm{BP}$ (SPb-1287), i.e. 6019-5621 cal. BC, Cherkasskaya site 3 , lower layer - $6715 \pm 64 \mathrm{BP}$ (Hela-3491), i.e. 5730-5525 cal. BC, Yarlukovskaya Protoka (point 222) - 6774 \pm 120 BP
(SPb-1637), i.e. 5903-5484 cal. BC. Pottery of the transitional phase can be dated to $6190 \pm 100 \mathrm{BP}$ (Ki-15959), i.e. 5400-4800 cal. BC, $6140 \pm 90$ BP (Ki-15432), i.e. $5300-4840$ cal. BC, $6050 \pm 90 \mathrm{BP}$ (Ki-15441), i.e. 5300-4700 cal. BC (Universitetskaya 3 site) (Smol'yaninov et al. 2017).

The second stage is characterised by the coexistence of pottery decorated with thin comb impressions and pottery decorated with triangular impressions and is dated from the end of the $6^{\text {th }}$ to the first half of the $5^{\text {th }}$ millennium BC (Gapochka 2001). It can relate to the penetration of the Early Eneolithic Lower Don Culture into the Don forest-steppe region, and the formation of the Cherkassky-type ceramic complex (Skorobogatov 2011). The amount of materials ascribed to the second stage is much higher. They are known both on the sites of the Voronezh River and the Don River: Universitetskaya 3, Universitetskaya 1, Karamyshevo 9, Ksizovo 6, Savitskoye, Kurino 1, Vasilyevsky Kordon 1, Lipetskoe Ozero, Cherkasskaya, and Cherkasskaya 3. This stage can be dated to $5770 \pm 200 \mathrm{BP}$ (SPb-1288), i.e. 5207-4246 cal. BC (Yarlukovskaya Protoka site) and Cherkasskaya site $-5997 \pm 33$ BP (Hela3771) i.e. 4985-4795 cal. BC. Food crust of Cherkassy-type pottery from the Cherkasskaya site was dated to $5763 \pm 32 \mathrm{BP}$ (Hela-3884), i.e. $4710-4535$ cal. BC. Single ${ }^{14} \mathrm{C}$ dates for materials of the early Eneolithic of the Don forest-steppe can be correlated with the second stage of the Middle Don Neolithic culture (Skorobogatov 2013).

The beginning of the third stage (the second half of the 5th mill. BC) is marked by active contacts with neighbouring territories - the Pitcomb Ware Culture and further contacts with the Eneolithic Lower Don culture. So far, there are no radiocarbon dates for this stage.

\section{Materials and study methods}

The Dobroe 9 site was discovered in 2014 by A.A. Klyukoyt (2015) in the washing away of a bank of the Voronezh River at the southern edge of the village Dobroe of the Lipetsk region on a 2-m-high bottomland residual hill above the river channel (Figs 1, 2). In 2017-19, A.A. Kulichkov and M.V. Sultanova excavated $98 \mathrm{~m}^{2}$ within the destroyed area (Kulichkov 2018a, b; Sultanova 2019). A total of 1,869 fragments of pottery, 207 stone artefacts and 476 bone finds, all attributed to Middle Don Culture, were discovered. 

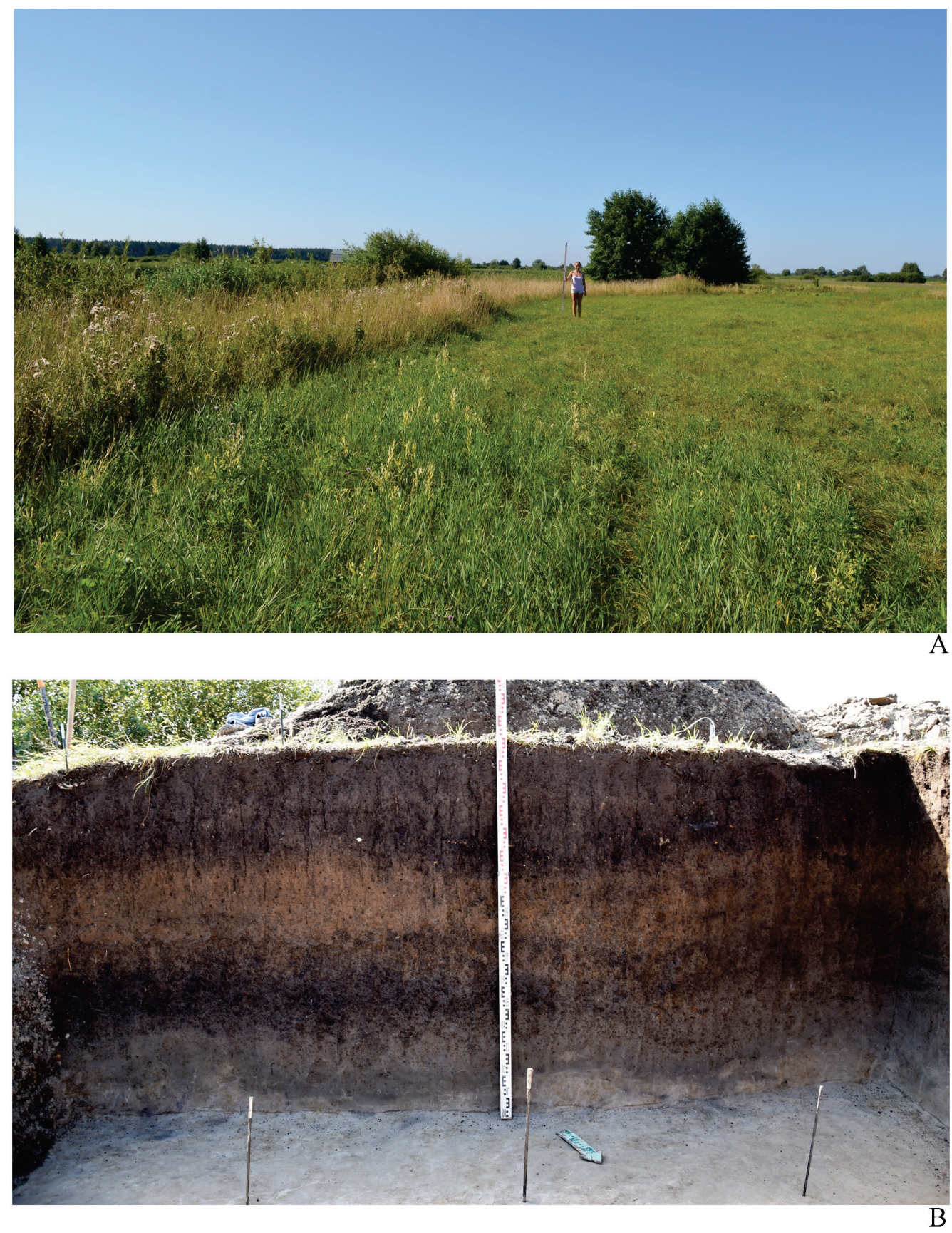

photo by R.V. Smolyaninov

Fig. 2. Dobroe 9 site

A - view of the site; $\mathrm{B}$ - studied wall of the excavation

The stratigraphy of the Dobroe 9 site:

0-5 cm b.g.l. - humic layer (topsoil); finds);

5-55 cm - dark grey loam (sterile layer, no

55-105 $\mathrm{cm}$ - red-brown loam (single finds from the Bronze Age $\left[3^{\text {rd }}\right.$ mill. BC], Early Iron Age $\left[1^{\text {st }}\right.$ mill. AD] and the Middle Ages $\left[13^{\text {th }}\right.$ $14^{\text {th }}$ c. $\left.\left.\mathrm{AD}\right]\right)$;
105-135 cm - black buried soil (finds attributed to the Middle Neolithic Lyalovo culture (the second half of the $5^{\text {th }}$ mill. BC) and Eneolithic Sredny Stog and Repinskaya cultures ( $4^{\text {th }}$ mill. BC);

135-160 cm - grey floodplain aleurite (artefacts attributed to the Early Neolithic Middle Don culture (the last quarter of the $6^{\text {th }}$ mill. BC). 
Geochemical indication method (Kul'kova 2012) and radiocarbon analysis were applied for palaeoclimatic reconstructions and dating of archaeological materials. X-Ray fluorescence analysis was applied for chemical analysis of sediments. The changes in palaeoclimatic factors influencing sedimentation (relative temperature, relative humidity, the index of chemical alteration) were evaluated by means of the geochemical indicators $\mathrm{Na}_{2} \mathrm{O} / \mathrm{K}_{2} \mathrm{O}, \mathrm{Fe}_{2} \mathrm{O}_{3} / \mathrm{CaO}$ and CIA (Fig. 3). The geo- chemical marker $\mathrm{P}_{2} \mathrm{O}_{5 \text { anthr }}$ is the indicator of anthropogenic activity (Kul'kova 2012).

The ceramic decorative pattern was analysed out according to the method proposed by Cetlin (2008). The following stylistic levels of ornamentation are described: element, pattern, motif, image and composition. The vessels' manufacturing technology was analysed using a binocular microscope according to the historical and cultural approach developed by Bobrinskiy $(1978,1999)$.

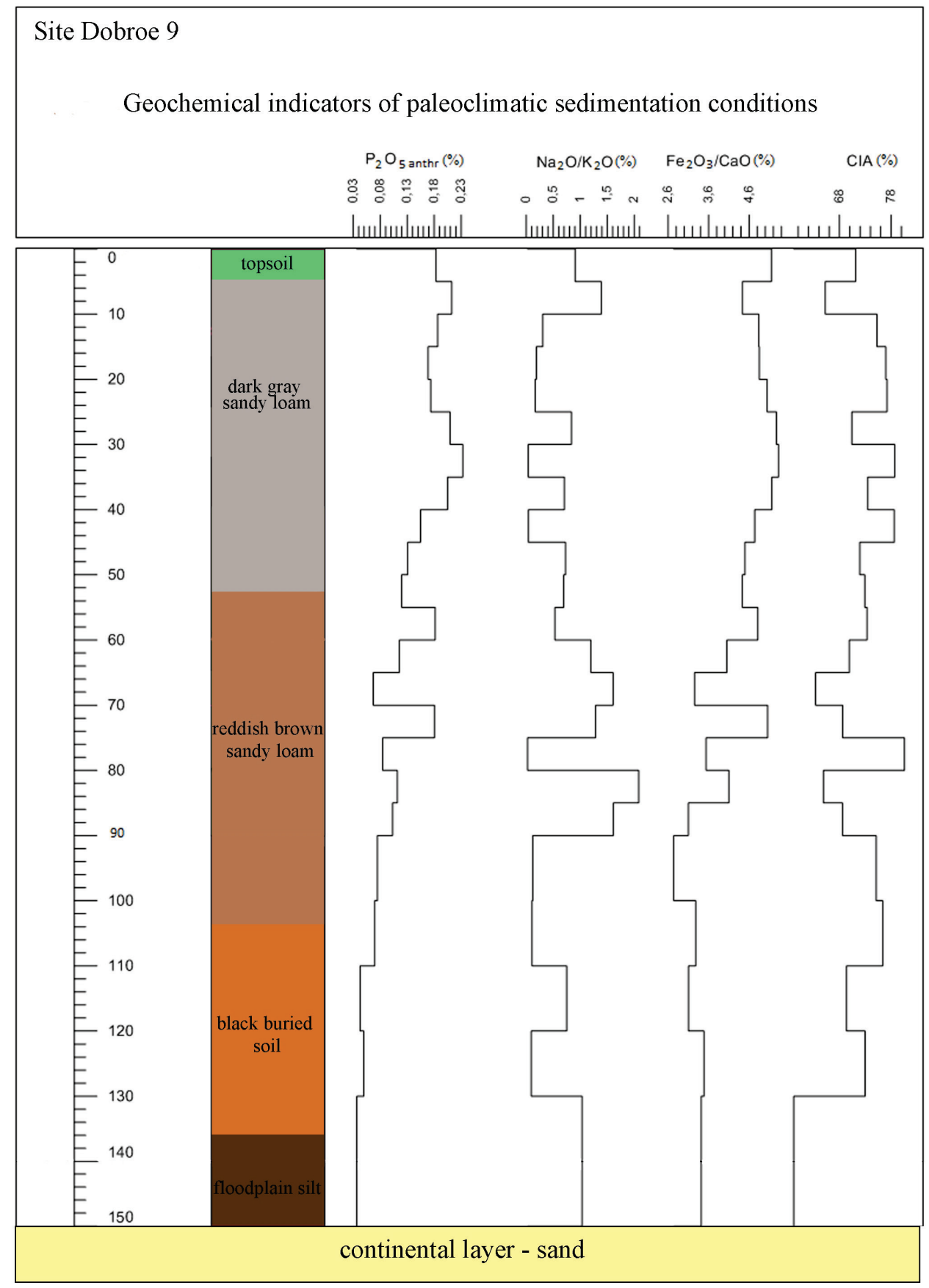

Fig. 3. Lithology and geochemical indicators of palaeoclimatic conditions at Dobroe 9 site 
Faunal collection analysis was processed according to Antipina (2011), and material preservation was described within the scale (1 to 5) noted by Antipina (2003).

\section{Results}

\section{Characteristic of ceramic assemblage}

At least 117 vessels were distinguished (according to rims) (Figs 4, 5, 6). Fragments of 14 bottoms were also revealed: 13 are rounded (Fig. 5: 4, 6; Fig. 6: 12) or conical (Fig. 5: 5; Fig. 6: 13, $16,20-22$ ) and only one is flat (Fig. 6: 19).

The vessels are of medium volumes from 12 $\mathrm{cm}$ in diameter up to large sizes of $46 \mathrm{~cm}$, with average values of $26-32 \mathrm{~cm}$, and a wall thickness of 4-7 mm. Five forms of the vessels' upper parts were distinguished:

1. The rarest form - an open bowl - is represented by only four vessels (Fig. 4: 9, 13, 16; Fig. 6: 2).

2. Cylindrical open form vessels (6 items) (Fig. 4: 1, 4; Fig. 6: 1, 14).

3. Profiled pots with varying degrees of profiling are represented by 12 vessels (Fig. 4: 24, 29-32; Fig. 5: 1, 14, 20; Fig. 6: 19).

4. A closed ovoid vessel, the rim bending inward (Fig. 4: 2, 5, 6, 10, 11, 17, 19, 21-23, 25, 27; Fig. 5: 3, 16, 17, 19; Fig. 6: 5-7, 9, 10, 11, 15, $18)$.

5. A straight-walled can (Fig. 4: 7, 8, 12, 14, 15, 18, 20, 26, 28; Fig. 5: 2, 7-9, 11, 12, 15, 18, 21; Fig. 6: 3, 4, 8).

A biconical form of the body can be reconstructed for some of them, as testified by five fragments of such vessel rib (Fig. 6: 17-19).

Only a small part of the vessel body is decorated. Ornamentation elements on the pottery of the Middle Don Culture from the Dobroe 9 site are represented by four types:

Type I. Triangular-oval form impressions. Subtypes: small triangular impressions (Fig. 4: 17, 18, 21, 24-26, 28, 32; Fig. 5: 19; Fig. 6: 18) and in rare cases - oval impressions (Fig. 5: 20) and staple-like impressions.

Type II. Impressions of a short comb stamp (Fig. 5: 7; Fig. 6: 1-3, 13, 14, 16, 17, 19).

Type III. Pits. Rounded small, with a diameter of 3-4 mm (Fig. 4: 14, 19, 24-32; Fig. 5: 1, 2, 7-9, 12, 13, 15-17, 19-21; Fig. 6: 1, 3, 4, 5-8, $10,11,15,19)$.

Type IV. Drawn lines. Not deep drawn lines of 1-2 mm thick (Fig. 4: 27; Fig. 5: 7).
The pottery ornamental motifs of the Middle Don Culture are divided into five types:

Type I - motifs from triangular-oval form impressions put in horizontal and oblique rows, in a line and separately.

Type II - motifs of short comb stamp impressions, composed in horizontal and oblique rows.

Type III - motif of small pits, put in horizontal rows, not more than two, in the upper part of the vessels.

Type IV - motif of drawn lines. An area of diagonally drawn lines deflected both to the left and to the right of the vertical axis of the vessel.

Type V - undecorated zones (the most widespread).

Manufacturing techniques of 17 vessels were analysed. Highly sandy silty clay was used for pottery manufacture; 14 samples were made of ferruginous raw materials, and three of nonferruginous. In all fractures of ceramics, in a concentration of 1-2 inclusions per square centimetre: 1) organic residues attested by cavities from burnt vegetation: leaves and stems of plants of various shapes and sizes (Fig. 6: 24); 2) quartz, rounded sand $0.2-0.4 \mathrm{~mm}$ in a concentration of $25 \%$ and $33 \%$ of the total mass. In eight samples, solid ferruginous particles of a rounded shape with a diameter of up to $4 \mathrm{~mm}$ were noted (Fig. 6: 25). The raw materials were used in a naturally moistened state; no traces of crushing were recorded. Organic solution as a temper was noted in three vessels, as attested by dark oily spots inside the sherd (Fig. 6:23).

The vessels were made from small slabs ranging from $1 \times 1$ to $1.5 \times 1.5 \mathrm{~cm}$, the direction of the building elements' junction lines is from the outer wall of the vessel to the inner, with circumferential overlap. Only one surface treatment method was noted - with a hard comb stamp, which could also be of a decorative nature in the vessels' processing (Fig. 5: 1). The mechanical strength of the vessels is medium. The fragments profile colour is three-layer. The layers are uneven in thickness, and the boundaries between them are slightly blurred, which indicates that, after firing, the vessels were left to cool for some time in the firing device. The data obtained allow us to suggest a bonfire firing with insufficiently long exposure at incandescent temperatures of 650 $700^{\circ} \mathrm{C}$, with a sharp increase and subsequent decrease in temperature, as reflected in the uneven thickness of the vessel layers (Vasil'eva 2002). 

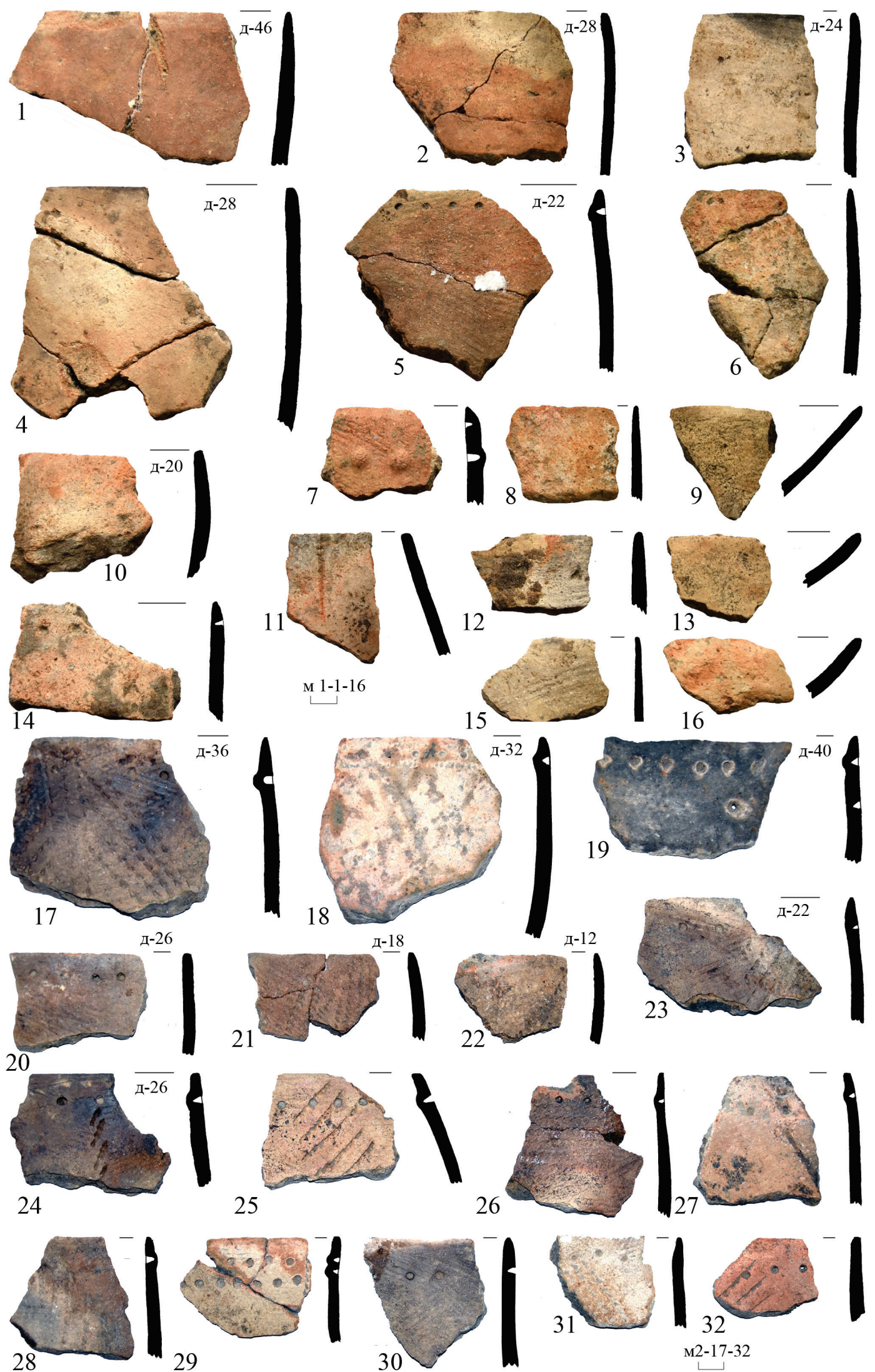

photo by R.V. Smolyaninov

Fig. 4. Dobroe 9 site. Pottery fragments of the Middle Don Early Neolithic culture 

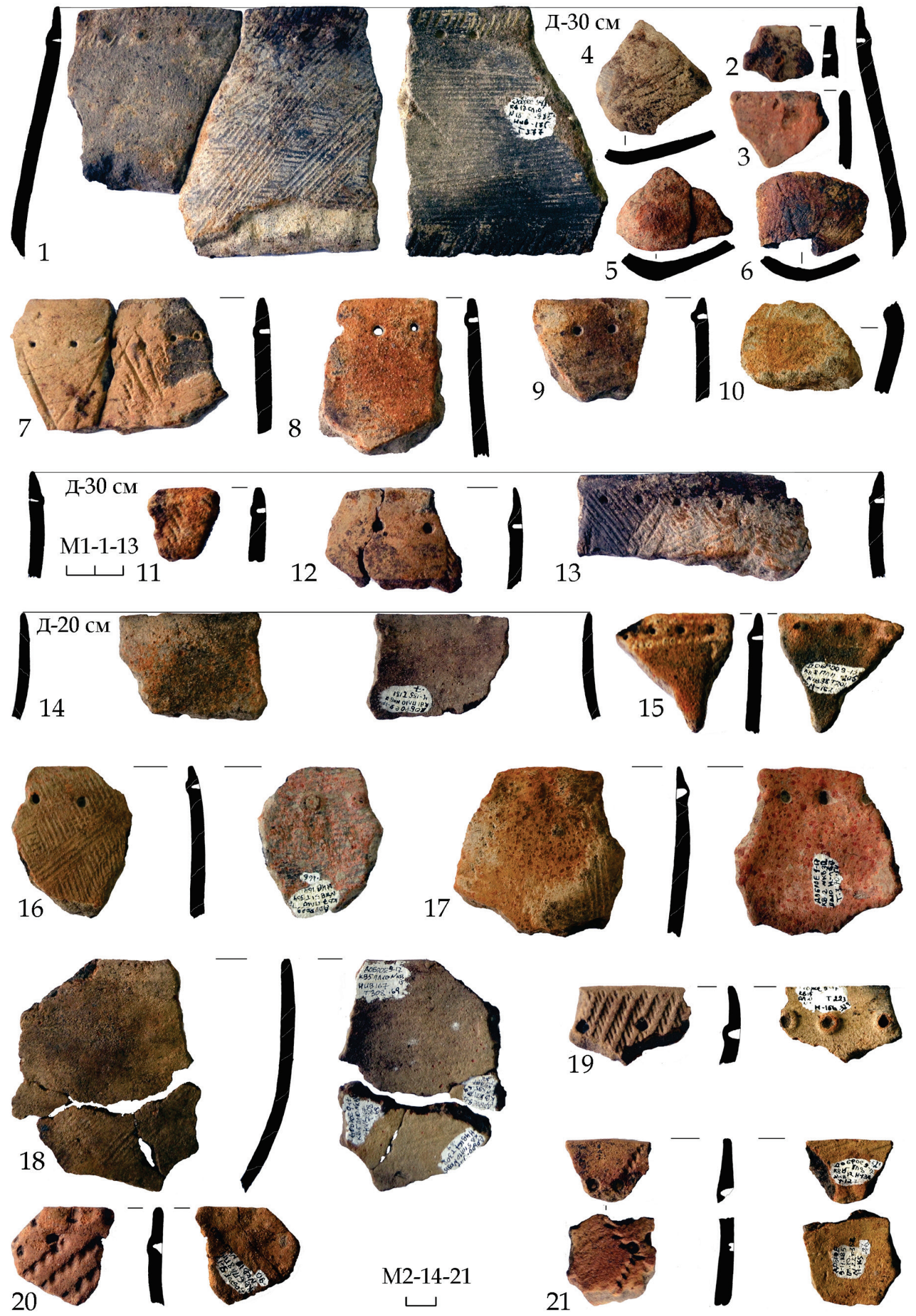

M2-14-21
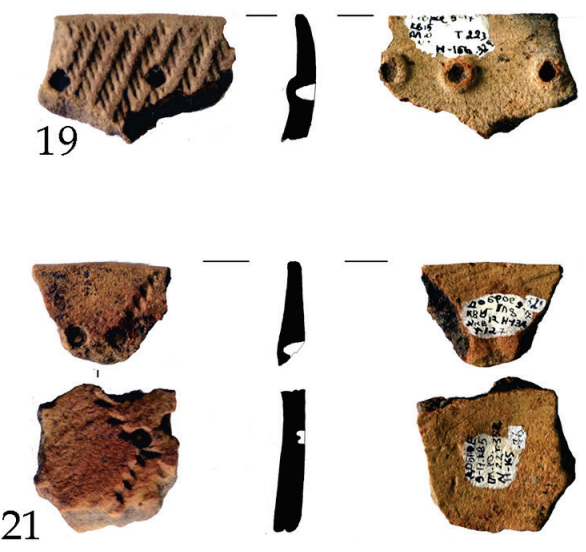

photo by R.V. Smolyaninov

Fig. 5. Dobroe 9 site. Pottery fragments of the Middle Don Early Neolithic culture 

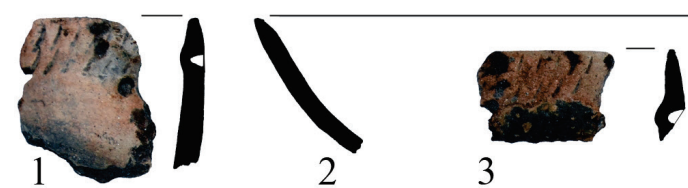

3
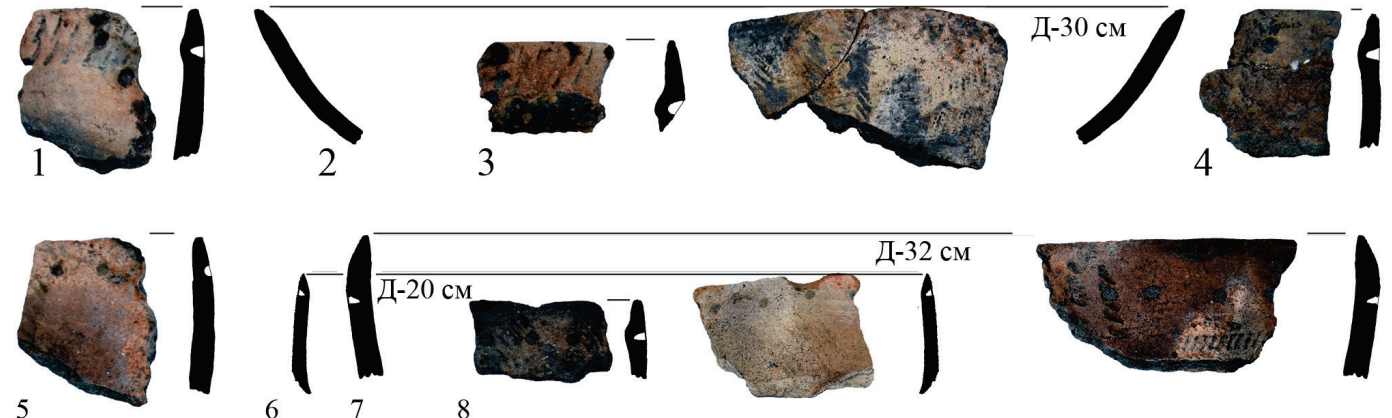

$6 \quad 7$

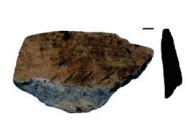

9

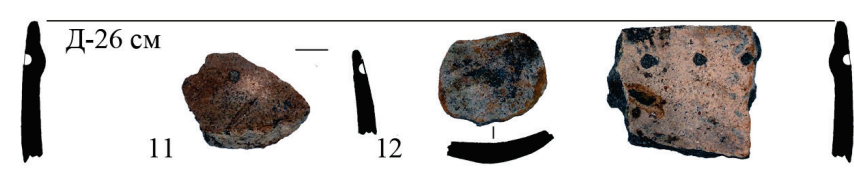

13
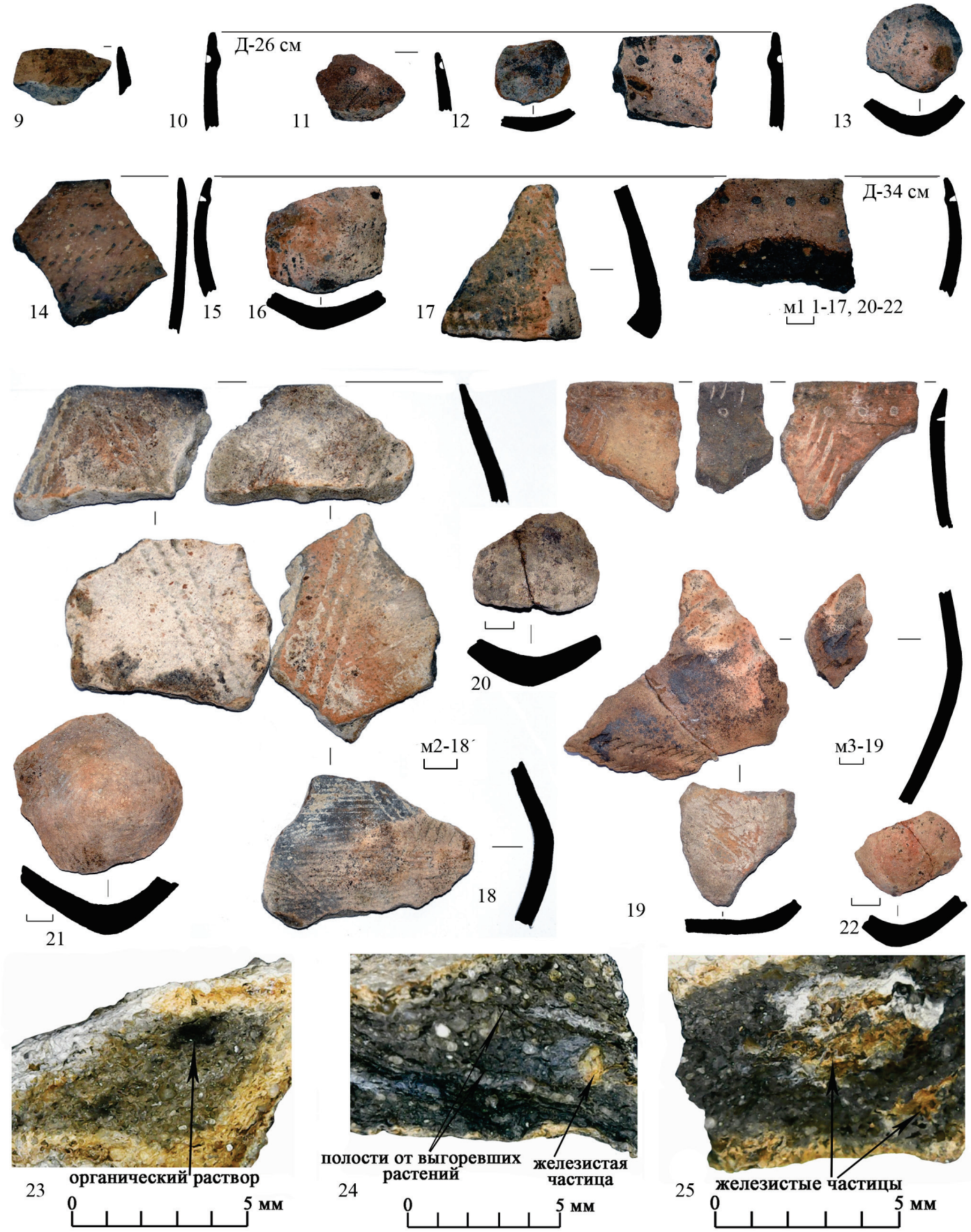

19
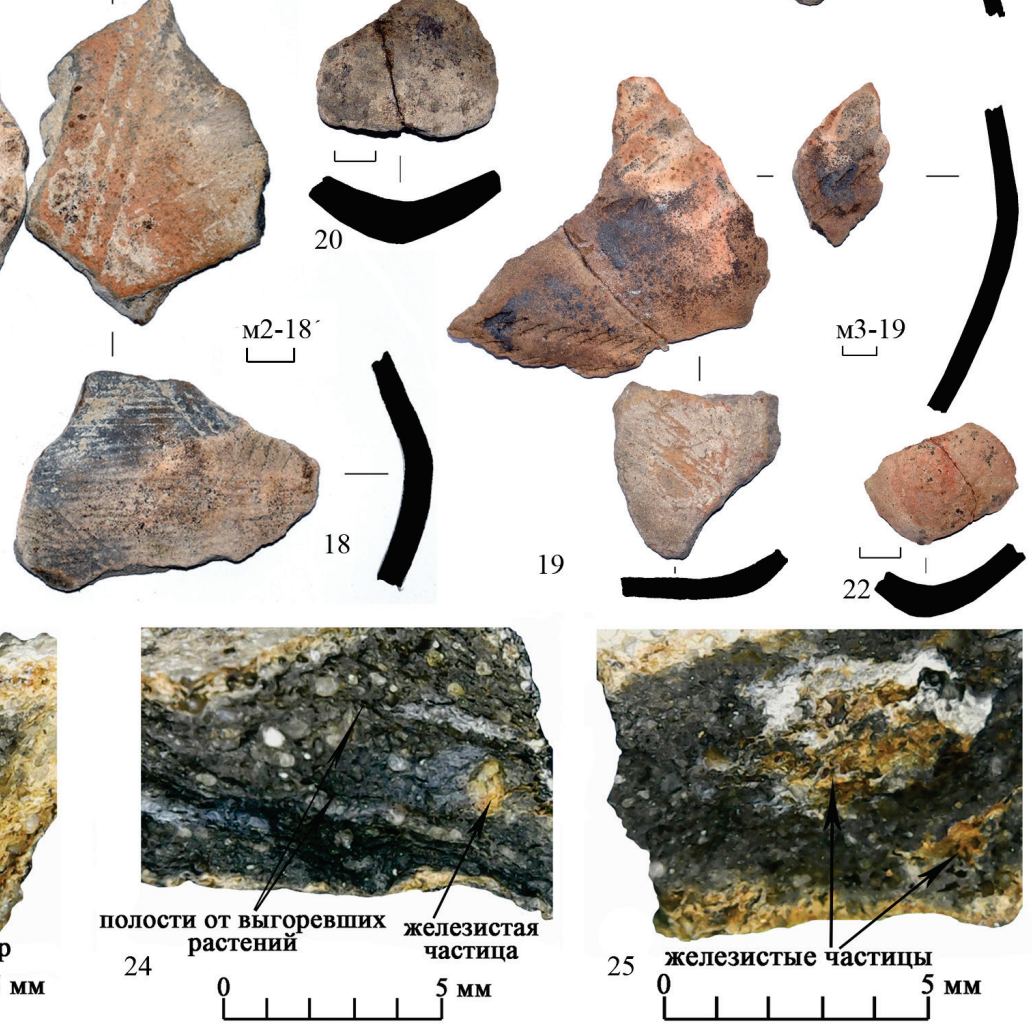

photo by R.V. Smolyaninov

Fig. 6. Dobroe 9 site. Pottery fragments of the Middle Don Early Neolithic culture 20-22 - microphoto of potsherd fractures 


\section{Features of stone artefacts}

A total of 207 pieces of stone artefacts were found, of which 142 pieces constitute production waste - flakes and fragments. In this group, 22 pieces with use-wear traces were recorded (Fig. 7: 8). Flint served as the main material for the tools' production, in rare cases quartzite, quartzite sandstone and sandstone were also used. The primary knapping products are presented by eight cores and one core-fragment for the flakes' manufacture (Fig. 7: 6; Fig. 8: 5), including one singleplatform prismatic core, one disc-shaped form and six multi-platform amorphous cores, which are characterised by an average and final degree of wear. The blade industry is almost absent. Only one irregular blade, section of the blade and blade flake with the traces of slight disposal were found (Fig. 7: 4; Fig. 8: 2, 3).

Tools and artefacts with traces of secondary processing include:

- one middle burin made on a flint sharp bend with a wedge-shaped cortex and two angular burins, one of which was made on a mediumsized flint flake (Fig. 8: 1) on whose cleavage an additional work is traced, and a second on a large quartzite flake (Fig. 7: 2);

- the largest group of the tools - end scrapers and their fragments - are represented by 23 specimens of various shapes and sizes (Fig. 7: 1, $3,5,7,9,10-12,14)$. Two fragments of heavy scrapers on the flakes are functionally close to the scrapers; they have one notch of $1.2 \mathrm{~cm}$ long (Fig. 8: 8);

- two borers on the flakes (Fig. 8: 4). Another laminar flake probably served as a perforator;

- a knife made on a large triangular flake (Fig. 8: 7). A fragment of the proximal part of the blade with a retouched edge on the dorsal side and partial correction with the ventral was probably also used as a knife;

- chopping tools are represented by a fragment of the blade part of a flint adze and a whole specimen (Fig. 7: 20) made of light brown flint by double-sided processing with subsequent edge retouching and grinding of the entire surface of the tool, as well as with an executed back edge. Its shape is elongated and oval-rectangular, and the blade part is slightly damaged;

- arrowheads are represented by one quartzite (Fig. 7: 17) and three flint arrowheads of a triangular shape with sharply pronounced asymmetric spikes. One of them is with a broken tang treated with bilateral pressure flaking. From the back and abdomen, it has traces of white patination (Fig. 8: 10). The second is treated with a two-sided exciting multi-faceted retouching and has a broken pike; the spikes are located in the middle of the product (Fig. 7: 16). The remaining two are partially retouched and have a rounded treated tang (Fig. 7: 17, 19). A flint arrowhead fragment was also found (Fig. 7: 18), from which it does not seem possible to determine the shape.

- a fragment of a polished flint product, a hammerstone, a quartzite scraper, an adze (?), a fragment of a chopping polished tool made of quartzite sandstone (?), and a flint fragment with traces of bifacial cleaving (Fig. 8: 9). In addition, 10 multifunctional tools were discovered (Fig. 7: $13,15)$. Five fragments of grinding plates were also identified. One is of sandstone, while the rest are of quartzite sandstone.

\section{Faunal collection}

The collections of the years 2017 and 2018 were processed, and 263 animal bones (from 93 specimens) were analysed. In total, 256 bones belong to mammals, five to mallards, one to a pike and one to a turtle. Material preservation is very poor - around 1-3 points (according to Antipina 2003). Many bones crumble into dust and it is not possible to identify them. Individual specimens bear traces of rodents gnawing. In total, eight mammal species were identified: elk (Alces alces) - 31 specimens; beaver (Castor fiber) - two; wild boar - three; wild ox - three; and lynx, marten, fox and wild horse - one specimen each. The most widespread species are wild animals, and are meat prey according to the archaeozoological classification (Antipina 2011). These species indicate the existence of large forests near the site. Amphibians are presented by one fragment of a tortoise plastron. In a single case, a charred bone was found - a highly calcified elk tooth. It was possible to determine the age in only one case - by the upper tooth, which belonged to an adult specimen.

Stratigraphic observations allowed us to suggest that almost all the definable bones of mammals, fish, birds, and amphibians (except for seven elk specimens associated with a layer of the Late Neolithic-Eneolithic of the second half of the $5^{\text {th }}$ to the first half of $4^{\text {th }}$ mill. BC) belong to the early Neolithic cultural layer of the Middle Don Culture, dating from the last quarter of the $6^{\text {th }}$ mill. BC. 

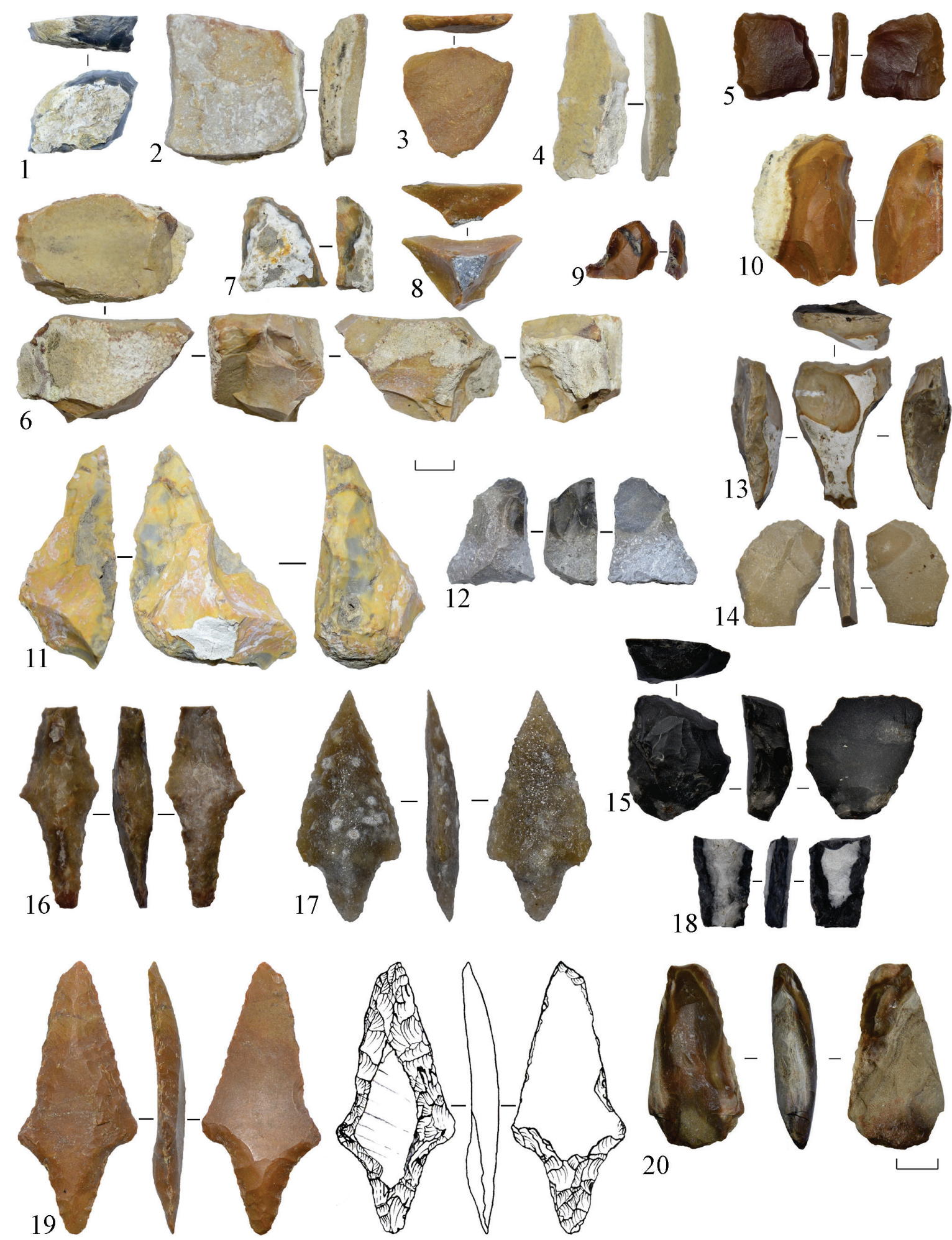

16-19

Fig. 7. Dobroe 9 site. Stone inventory

1, 3-16, 18-20-flint artefacts; 2,17 - quartzite artefacts 

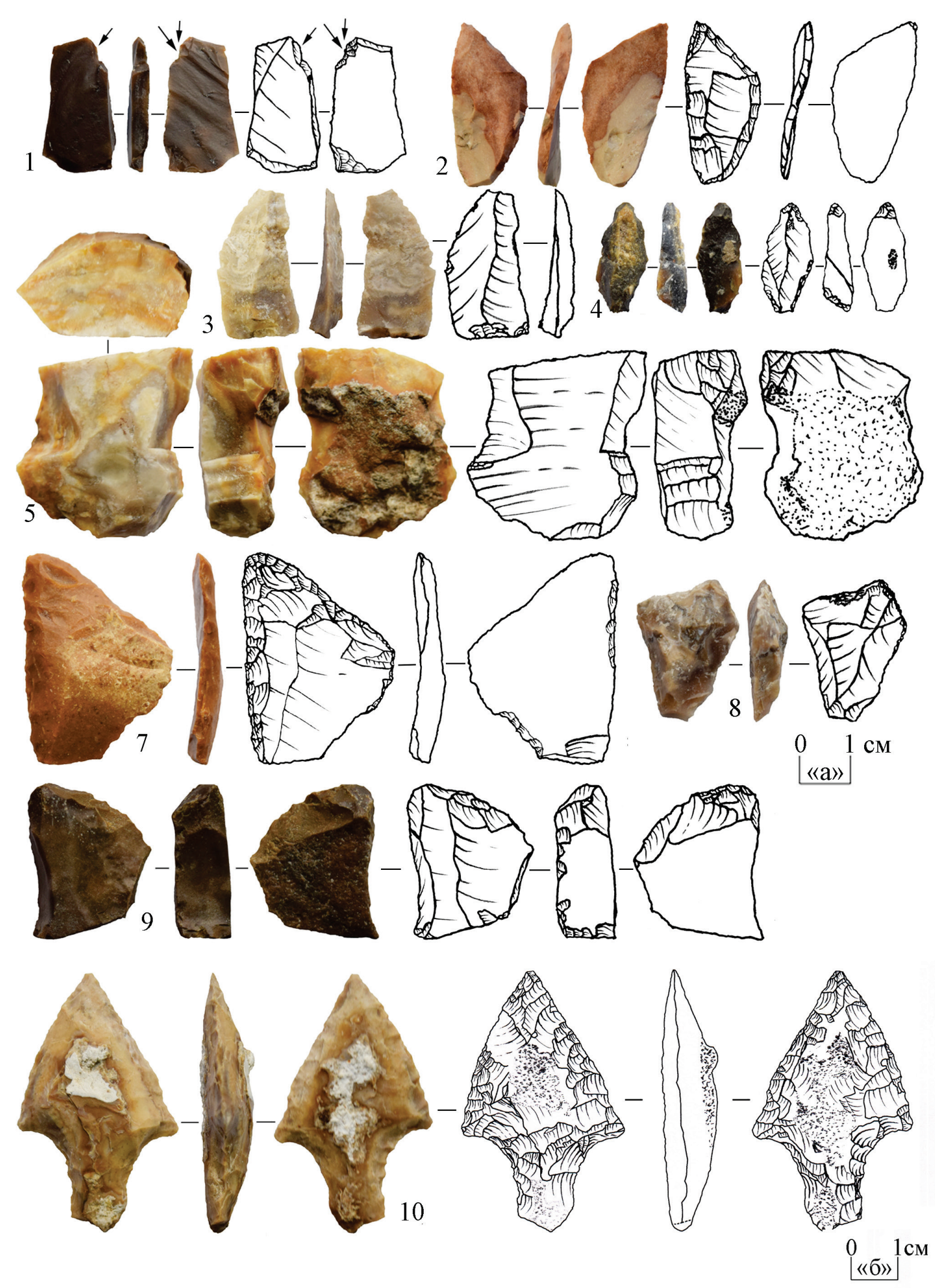

photo by E.S. Yurkina

Fig. 8. Dobroe 9 site. Stone inventory 


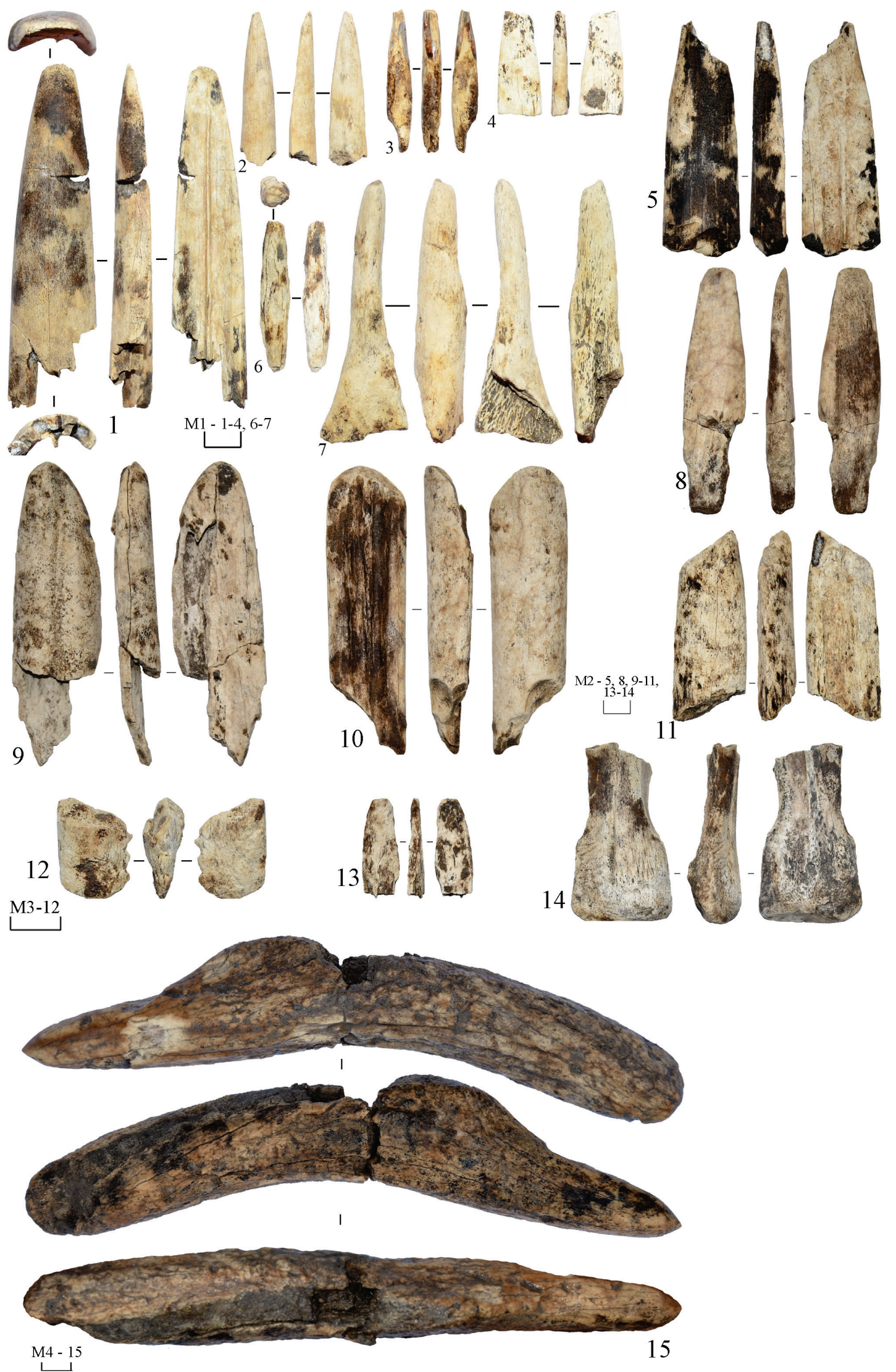

photo by E.S. Yurkina

Fig. 9. Dobroe 9 site. Bone and antler artefacts 


\section{Reconstruction of bone industry}

The bone-processing techniques include: cutting, chipping, abrasion, polishing. The tubular bones were used as the main semi-finished; in a single case, a processed rib and a product from a pig's fang were noted (Fig. 9: 3). Five types of hunting and fishing tools were distinguished. The points group includes arrows, points and harpoons. Due to the products' fragmentation, they cannot always be ascribed precisely to a specific type. Part of the fragmented point (Fig. 9: 2) is distinguished by a careful processing of the entire surface. The preform was a quadrangular rod cut by a cutter and then levelled by chopping. The final shape was given to the tip by abrasive treatment: signs of abrasion are well traced in the form of thin linear traces. The middle of the tip of the spike has a deepening resembling a groove. One spike with a relatively short feather and a flattened-oval section was noted (Fig. 9: 8), as well as one middle fragment of a spike that has traces of polishing (Fig. 9: 5). Due to poor preservation, two other fragments of a flattened spike (Fig. 9: 4, 13) are not subject to further classification. The harpoon (?) fragment (Fig. 9: 12) is highly fragmented and on the remaining part has three small beak-shaped teeth on one edge. Also, tools for working with soft material were found. There are three fragments of gloss (Fig. 9: 1, 8, 10), one of which is made of large elk bone and has a sharpened rounded edge and polishing marks. One tool fragment that may have been used as an awl is of interest (Fig. 9: 7). Some products (Fig. 9: 6, 11, 14) cannot be attributed to any types. An artefact made from antler was interpreted as a zoomorphic figure with one end possibly elaborated into the form of a bird head (Fig. 9: 15). Only the basic characteristics are conveyed: an oval body and a curved head with a narrowing at the end. Other traces of stylisation were not noted. Analogies to these artefacts can be found in the Oka River basin in the materials of a multilayer site of Shagar II and Chernaya Gora (Kashina, Emel'yanov 2003), though attributed to the Late Neolithic.

\section{Palaeoclimatic reconstructions}

In the lower cultural layer of the Early Neolithic of the Middle Don Culture, represented by grey aleurite, the markers of relative temperature $\left(\mathrm{Na}_{2} \mathrm{O} / \mathrm{K}_{2} \mathrm{O}\right)$ and relative humidity $\left(\mathrm{Fe}_{2} \mathrm{O}_{3} / \mathrm{CaO}\right)$ increased - the cool climatic conditions changed to warming and increased humidity. The human activity also increased, as demon- strated by specific geochemical indicators. This lithologically homogeneous cultural layer of the Middle Don Culture was dated to $6150 \pm 100$ BP (SPb-2840), i.e. 5317-4839 cal. BC, based on the dating of organics from the soil.

\section{Discussion}

The particularity of the sedimentation process and deposition of further artefacts in the lithological layers at the Dobroe 9 site made it possible to correlate different categories of materials with the horizon of the pottery assemblage of the Middle Don Culture. At the sites of the Upper Don Region with materials of the Middle Don Neolithic culture, the pronounced flaking technique for manufacturing tools dominates. The prevalence of the flaking technique over blade technology can be marked. The number of cores implemented for processing blades is very low. The tools are typologically very heterogeneous. Only single burins were found. There are grinding stones made of sandstone or quartzite sandstone with extensive working surfaces at every site. However, the percentage of the polished products is very low. Triangular arrowheads with sharply pronounced asymmetric spikes found at the Dobroe 9 site can be securely attributed now to Middle Don Early Neolithic culture. The arrowheads in the ForestSteppe Don Region of the Neolithic era are a rare class of stone products. Similar types of arrowheads were found in the Upper Don basin - at the Lipetskoe Ozero site (Sinyuk, Klokov 2000) and in the Middle Don: at the Cherkasskaya and Dronikhinskaya sites on the Bityug river (Sinyuk 1986). An extremely small number of stone artefacts can be found at early Neolithic sites on the Upper Don, which partially attests to their possible replacement by products of other activities: bone-carving and woodworking (Smol'yaninov, Yurkina 2018).

The Middle Don Culture existed within a wider geographical area of the steppe and foreststeppe areas where the earliest pottery appeared. Similar studies were carried out in the Lower Volga region. The early stage of the Middle Don Culture in the Middle and Upper Don area can be correlated with the Orlovskaya Culture (second stage) distributed in the Lower Volga region (5800-5500 cal. BC, Algay site) during a period of humid and warm climate (Kulkova et al. 2019). The decrease in human activity documented at the Algay site correlates with cold and dry conditions at 5660-5560 cal. BC. In the later stage of the Orlovskaya Culture (5300-5200 cal. BC) the 
climate became more humid and warmer, and there were significant changes in the material culture of this stage, probably influenced by newcomers. This stage is synchronous with middle stage of the Middle Don Culture dated to $5300-4850$ cal. BC; in this period the climatic conditions were warm and humid after a cooling. According to Gerasimenko (1997), the climatic Holocene optimum in the steppe zone was registered during 5500-4500 cal. BC. Probably, the favourable climatic conditions promoted the spread of Neolithic groups in different regions, from the south to the north.

\section{Conclusion}

The Dobroe 9 site is a reference point for understanding the processes of Neolithisation of the forest-steppe zone of the Upper Don. Pottery found here can be attributed to a transitional phase dated to the last quarter of the 6th millennium BC. It includes both vessels decorated mainly with triangular impressions and later phases when comb impressions became widespread. Preliminary geochemical studies demonstrated the coincidence of increased anthropogenic activity and warmer, more humid climatic conditions. This correlates with the nature of archaeological deposits in a stratigraphic context: as the climate conditions improved, anthropogenic activity also increased (lower and upper cultural layer); when the conditions became colder and humidity decreased (a layer of deposits between the cultural layers where the geochemical indicators changes are recorded), the anthropogenic activity decreased.

Further detailed investigations of both geochemistry of archaeological deposits and archaeological collections at different Neolithic sites are needed for reconstructions of cultural processes and their connection with climatic changes in the basin of the Upper Don.

\section{Acknowledgments}

This publication was prepared with financial support from the RFBR (Russian Foundation for Basic Research) grant No. 18-49-480004 "Site Dobroe 9 in the system of the Early Neolithic antiquities of the forest-steppe Don Region" and the grant from the Foundation for Presidential Grants "Following the Traces of an Ancient Man" No. 19-2-018793.

\section{References}

Antipina Ye.Ye. 2003. Arkheozoologicheskiye issledovaniya: zadachi, potentsial'nyye vozmozhnosti i real'nyye rezul'taty. Novyye arkheozoologicheskiye issledovaniya v Rossii. In: Ye.Ye. Antipina, Ye.N Chernykh (eds) Noveyshiye arkheozoologicheskiye issledovaniya $v$ Rossii. Yazyki slavyanskoy kul'tury, Moskva: 7-34.

Antipina Ye.Ye. 2011. Pereyaslavl' Ryazanskiy, kreml', XVII vek: osteologicheskaya kollektsiya. Analiticheskiye issledovaniya laboratorii yestestvennonauchnykh metodov. In: Ye.N. Chernykh, V.I. Zav'yalov (eds) Analiticheskiye issledovaniya laboratorii yestestvennonauchnykh metodov. Institute of Archeology of the Russian Academy of Sciences, Moskva: 204213.

Bobrinskiy A.A. 1978. Goncharstvo Vostochnoy Yevropy. Istochniki i metody izucheniya. Nauka, Moscow.

Bobrinskiy A.A. 1999. Goncharnaya tekhnologiya kak obekt istoriko-kulturnogo izucheniya. In: A.A. Bobrinskiy, I.H. Vasil'yeva, N.P. Salugina (eds) Aktualnye problemy izucheniya drevnego goncharstva: kollektivnaya monografiya. Samara State Pedagogical University, Samara: 5-109.

Cetlin Y.B. 2008. Neolit centra Russkoj ravniny: ornamentaciya i metodika periodizacii kul'tur. Grif and K., Tula.

Gapochka S.N. 2001. Neoliticheskie pamyatniki s nakol'chatoy i nakol'chato-grebenchatoy keramikoy lesostepnogo Dona. Avtoreferat dissertatsii na soiskanie uchenoy stepeni kandidata istoricheskikh nauk. Voronezh: 1-28.

Gerasimenko N.P. 1997. Natural human habitat in the south-east of Ukraine in the Late Ice Age and Holocene (based on the materials of paleogeographic study of archaeological sites). Archaeological Almanac. 6: 3-64.

Kashina E.A., Emel'yanov E.A. 2003. Kostyanye izobrazheniya ptic finala kamennogo veka Meshcherskoj nizmennosti. Problemy drevnej i srednevekovoj arheologii Okskogo bassejna. In: V.P. Chelyapov (ed.) Problemy drevney i srednevekovoy arkheologii Okskogo basseyna. Sbornik nauchnykh rabot. Ryazan': 53-70.

Klyukoyt A.A. 2015. Otchet o provedenii razvedochnykh rabot v srednem techenii r. Voronezh na territorii Dobrovskogo, Gryazinskogo i Lipetskogo rayonov Lipetskoy oblasti v 2014 godu. Arkhiv IA RAN. R-1.

Kulichkov A.A. 2018a. Otchet o provedenii razvedochnykh issledovaniy $\mathrm{v}$ basseyne $\mathrm{r}$. Voronezh $\mathrm{v}$ predelakh Dobrovskogo rayona Lipetskoy oblasti, Michurinskogo rayona Tambovskoy oblasti v 2017 g. Arkhiv IA RAN. R-1.

Kulichkov A.A. 2018b. Otchet k otkrytomu listu № 1927 ob arheologicheskih issledovaniyah na territorii vyyavlennogo ob"ekta arheologiches- 
kogo naslediya «Poselenie Dobroe 9» v Dobrovskom rajone Lipeckoj oblasti v 2018 g. Arhiv IA RAN. R-1.

Kul'kova M.A. 2012. Metody prikladnyh paleolandshaftnyh geohimicheskih issledovanij, uchebnoe posobie. Izd-vo RGPU, Sankt-Peterburg.

Kulkova M., Vybornov A., Yudin A., Doga N., Popov A. 2019. New interdisciplinary research on Neolithic-Eneolithic sites in the Low Volga River region. Documenta Praehistorica XLVI: 376-387.

Levenok V.P. 1965. Dolgovskaya stoyanka i yeyo znacheniye dlya periodizatsii neolita na Verkhnem Donu. Materials and research on archeology of the USSR 131: 223-231.

Mil'kov F.N. 1961. Srednyaya polosa evropeyskoy chasti SSSR. Geografgiz., Moskva.

Smolyaninov R., Skorobogatov A., Surkov A. 2017. Chronology of Neolithic sites in the forest steppe area of the Don River. Documenta Praehistorica XLIV: 192-202.

Sinyuk A.T. 1986. Naselenie basseyna Dona v epokhu neolita. Voronezh University Publishing House, Voronezh.
Sinyuk A.T., Klokov A.YU. 2000. Drevnee poselenie Lipeckoe Ozero. Lipetsk publishing house, Lipeck.

Skorobogatov A.M. 2011. Eneoliticheskie pamyatniki Donskoy lesostepi. Dissertatsiya na soiskanie uchenoy stepeni kandidata istoricheskikh nauk. Voronezh.

Skorobogatov A.M. 2013. Eneolit basseyna Verkhnego i Srednego Dona v svete novykh dannykh. In: I.N. Chernykh (ed.) Tverskoy arkheologicheskiy sbornik 9. Triada, Tver: 264-278.

Smol'yaninov R.V., Yurkina E.S. 2018. Kamennaya industriya rannego neolita Verhnego Dona. Samarskiy nauchnyy vestnik 3(24): 189-199.

Sultanova M.V. 2019. Otchet k otkrytomu listu № 1211-2019 o raskopkah stoyanki Dobroe $9 \mathrm{v}$ Dobrovskom rajone Lipeckoj oblasti v 2019 g. (unpublished).

Vasil'eva I.N. 2002. O tekhnologii keramiki I Hvalynskogo eneoliticheskogo mogil'nika. Voprosy arheologii Povolzh'ya 2: 15-49.

Zamyatnin S.N. 1922. Ocherki po doistorii Voronezhskogo kraya: Kamennyy i bronzovyy vek v Voronezhskoy gub. Voronezh. 